\title{
Regional Integration, Growth and Convergence
}

\author{
Dirk Willem te Velde \\ Overseas Development Institute
}

\begin{abstract}
This paper examines empirically whether and how regional integration leads to convergence and growth amongst developing countries. Using standard growth models for nearly 100 developing countries over 1970-2004 we cannot establish robust growth effects of regional integration as such at the aggregated level of analysis even after using alternative measures of regional integration. However, because we find that trade and FDI promote growth, and because regional integration tends to increase trade and FDI, regional integration still has a positive impact on growth in its members through the effects of increased trade and investment on growth. Further, country-specific growth diagnostics do suggest that regional integration can be a binding constraint to growth as "deep" regional approaches can help to address crucial rail, road, air and energy links amongst countries (e.g. in the East African Community). Our findings also suggest that initially high levels of regional income disparities will lead to greater decreases in disparities. Whilst the level of intra-regional trade and incomes do not explain changes in income disparities, the presence of a regional Development Finance Institutions (e.g. Central American or East African development banks) with a relatively high loan exposure to GDP ratio tends to reduce regional income disparities suggesting a useful role for deeper integration in achieving regional cohesion. A one percentage point increase in exposure by DFIs leads to a drop of $\sigma$ of about one percentage point. Finally, while the macro economic literature on regional integration tends to highlight only limited expected effects of African regional integration itself, our work at the firm level in three African countries (Benin, Malawi and South Africa) is indicative of significant dynamic effects of

\footnotetext{
*Corresponding address: Head of Programme of the International Economic Development Group at the Overseas Development Institute. Tel 0044 (0) 20 79220300; dw.tevelde@odi.org.uk; Fax 0044 (0) 20 79220399; 111 Westminster Bridge Road, SE1 4JY, London, UK

(C)2011-Center for Economic Integration, Sejong Institution, Sejong University, All Rights Reserved.
} 
regional integration through the effects on firm level productivity in Africa. We suggest that in the future, further growth analytical work is undertaken which combines the development of methods to examine the effects of regions and measurement of the various types of regional integration.

- JEL Classification: F15, F21, F43, O47

- Keywords: Economic Growth, Foreign Direct Investment, Economic Integration, Convergence.

\section{Introduction}

This paper examines empirically whether and how regional integration leads to convergence and growth amongst developing countries. The empirics focus on developing country regions with most attention to African countries. There is a large literature on the economic welfare effects of regional integration (Viner, 1950) and an emerging one on convergence within regions. But there are gaps in the empirical literature examining the relationship of different types of regions and different types of economic performance at macro and micro effects.

The paper attempts to address a number of different but interrelated observations on research on regions. Not all regions are formed for economic reasons, yet politicians in all regions are interested in growth effects. Whilst a significant amount of research on regional integration is on the effects at regional level, individual countries are concerned with impacts at the level of the country especially as it is unlikely that the benefits are the same across all countries in the region. Much empirical research focuses on regions and entities that do not change and treats regions the same (they either exist or they do not), while we know that no region is the same. Much of the earlier work on regions considers static allocative effects at the macro level, yet the literature on new regionalism emphasises dynamic effects at the micro level. We try to fill these gaps and aim to apply a number of new analytical techniques to the study of regional integration, growth and convergence.

This paper is structured as follows. Section II provides the background on the theories of regional integration, growth and convergence and highlights the main hypotheses. Section III describes the growth analytics used to understand the effects of regional integration. Section III describes the performance of regions on the basis of a number of variables. Section IV provides the empirical results. 
Section V presents the conclusions from the research.

\section{Regional Integration, Growth and Convergence: Theoretical Considerations}

This section introduces a number of aspects of the literature on regional integration relevant for this study.

\section{A. Trade diversion or trade creation}

The literature on regional integration dates back to at least Viner (1950) who suggested that the effects of regional integration on trade can be either trade creating when trade replaces or complements domestic production, or trade diverting when partner country production replaces trade from the rest of the world. If a country becomes a member of a region that "diverts" trade to its members it would have been better to liberalise globally.

\section{B. Narrow and deep integration}

Regions classifying as Regional Trade Agreements (RTAs) under Article XXIV of the GATT (trade in goods) or Article V of the GATS (trade in services) will have to liberalise substantially all trade. There are exceptions under each when it concerns regions amongst least developed or developing countries. The mere reduction or elimination of tariffs on intra-regional trade will have fewer effects if the potential for intra-regional trade is small. For instance, Te Velde (2006) argues that intra-regional trade in Africa covers only a small percentage of total trade, in part because economic and trade (in final products) structures are similar (but perhaps also because of underreporting), so any trade (and hence economic) effect of lower tariffs is likely to be small. Instead, researchers have argued that deep integration covering trade rules, trade standards and institutional co-operation would be better for regions, see e.g. Gasiorek and Holmes (2008).

\section{Regional trade provisions or providing regional public goods}

There are other roles for regional integration, beyond trade provisions. First, regions can support the provision of regional governance public goods. Effective international economic governance promotes economic development. Some challenges are best met at the national or multilateral level, but some policymaking occurs at a regional level in parallel with national trade policy-making. 
There has been an increase in regional policy-making and in the number of regional trade agreements over the past decades. As these evolve to consider deeper regional integration, particularly the liberalization of sensitive service sectors or the provision of social projects (which make sense in a regional context) (te Velde, 2006), there is a need for regional institutional development and regional governance. Second, regions can support the provision of regional knowledge public goods. A regional approach facilitates learning and sharing of information related to trade development and trade policy or other areas of functional cooperation such as agriculture and food security, environmental (e.g. water) and health (communicable diseases) governance. Finally, regions can overcome other market and coordination failures and coordinate activities with strong regional externalities. Many competitiveness challenges are regional in nature; for instance, a landlocked country is dependent on appropriate infrastructure in other countries for trade in goods. Some externalities are not geographically limited to a region, but others relate to neighbouring states only. National development programmes will not normally consider activities with strong international externalities as benefits cannot be fully appropriated nationally. IMF/World Bank (2006) discusses a power project benefiting Malawi, but with a need for financing in Mozambique.

\section{Static or dynamic effects}

RTAs can affect growth through dynamic output and productivity effects such as through competition and scale. Many argue that important effects of RTAs are dynamic, with competition creating a more efficient industry and growth. Lower intra-regional tariffs would lead to increased competition (Neary, 2001). The new trade theory emphasises long-run productivity effects of trade (Grossman and Helpman, 1991). Productivity spillovers can occur via importing and exporting (Coe and Helpman, 1995; Coe, Helpman and Hoffmeister, 1997). Not only does a country's efficiency increase due to allocation effects, trade helps actors to learn from each other and appropriate R\&D spillovers. These learning effects can be translated into long-run efficiency gains. Blomstrom and Kokko (1997) argue that regional integration leads to efficiency gains and higher growth. Increased FDI can actually be such a catalyst through spillovers in terms of technology transfer and other linkages with local firms. There can thus be long-lasting effects on growth and productivity in addition to a one-off effect based on a more efficient allocation of resources.

The empirical evidence on the effects of regional integration on growth remains 
disputed. Vamvakidis (1998) estimates cross-country and time-series growth regressions over 1970-90. He finds that open economies grow faster and that economies that have open and large neighbours grow faster; but the growth rate of neighbouring economies has no significant impact on a country's growth rate. Countries tend to benefit from being located close to large, developed, and open economies. Vamvakidis examines the impact of ASEAN, the Andean Pact, the CACM, UDEAC, and the EU on the growth in its members. He finds no significant impact for any except the European Union and suggests that SouthSouth agreements among small, closed developing countries are unlikely to lead to faster growth.

Schiff and Wang (2003) find that "there has been no empirical evidence of the dynamic effects of RIAs (Regional Integration Agreements) based on their impact on technology diffusion from partner and non-partner countries". They then go on to show that NAFTA imports has raised productivity (between 5.5-7.5\%) in Mexico through imported foreign knowledge stocks, while extra-regional imports did have no effects. These are long-lasting effects that can in the long-run benefit the poor. There can also be long-lasting effects on productivity through learning by-exporting, and such effects may be appropriated particularly when dealing with more developed partners and these tend to be extra-regional.

\section{E. Micro or macro effects}

Much of the early literature on regional integration or integration more generally emphasizes the allocative effects at the macro level: some sectors with a comparative advantage gain at the expense of other sectors. However, the discussion on dynamic effects suggests that the effects work at the firm level (although dynamic effects might also be due to entry and exit of firms).

\section{F. Convergence or divergence}

The benefits of regional integration may not be evenly spread amongst members of a region. It will be of interest to examine whether regional integration helps convergence amongst members, and if so under what conditions and what aspects of regional integration. Ethier (1998) suggests that smaller countries may have incentives to form a region in order to attract investment away from other members, particularly extra-regional FDI. This may be the case when regional tariff preferences allow foreign investors to set up beachhead locations in a small (or poor) country to serve the entire regional market. Venables (1999) on the other 
hand argues that South-South agreements will tend to lead to divergence of income levels of members states, while North-North agreements may lead to convergence of income levels. The explanation of this is based on the position of countries in a region compared to those outside the region. Countries with a comparative advantage (e.g. in manufacturing) closer to the world average do better in a region than do countries that are at the extreme position as the latter are more likely to switch import suppliers (of manufactures) and face trade diversion costs. Possible divergence due to relocation effects may put RIAs under strain. While peripheral countries to the EU such as Ireland caught up during the 1990s in terms of productivity levels with other members of the EU apparently through trade and FDI spillovers, there was a degree of divergence and agglomeration in developing regions such as East African Community and the Central American Common Market both dating back to the 1950s and 1960s.

Te Velde and Bezemer (2006) estimate a model explaining the real stock of UK and US FDI in developing countries during 1980-2000 and find that membership of a region as such is not significantly related to inward FDI, but crucially, when a country is a member of a region with a sufficient number and level of trade and investment provisions (e.g. provisions describing treatment of foreign firms, large trade preferences), this will help to attract more inward FDI to the region. Important for the debate on convergence and divergence within regions, they find that the relative size of a country's economy within a region matters for attracting additional FDI, as does a central location in relation to the largest market. Countries that have larger economies or are geographically closer to other, larger countries within the region can expect a larger increase in FDI as a result of joining than those of countries that have smaller economies or are located in the periphery.

\section{Regional Integration, Growth and Convergence: Growth Analytical Techniques}

There is a wide variety of growth analytical techniques that can be used to examine the effects of regional integration on economic performance. General equilibrium modeling could form an important part of any analysis, however this paper focuses on econometric and statistical techniques only.

\section{A. Growth analytical techniques at the macro level}


Table 1. Regional Integration Index

\begin{tabular}{|c|c|c|c|c|c|c|}
\hline \multirow[b]{2}{*}{$\begin{array}{l}\text { RTA (date of } \\
\text { establishment) }\end{array}$} & \multicolumn{3}{|c|}{ Investment provisions } & \multicolumn{3}{|c|}{ Trade provisions } \\
\hline & 1970s & 1980s & $1990 s$ - & 1970s & 1980s & 1990s - \\
\hline NAFTA (1994) & 0 & 0 & $3(1994)$ & 0 & 0 & $2(1994)$ \\
\hline MERCOSUR (1991) & 0 & 0 & $2(1994)$ & 0 & 0 & $3(1991)$ \\
\hline CARICOM (1973) & $\begin{array}{c}0 \\
-1(1970)\end{array}$ & $1(1982)$ & $2(1997)$ & $1(1973)$ & 2 & $3(1997)$ \\
\hline ANDEAN (1969) & & $1(1987)$ & $2(1991)$ & 1 & 1 & $2(1993)$ \\
\hline ASEAN & 0 & $1(1987)$ & $\begin{array}{l}2(1996), \\
3(1998)\end{array}$ & 1 & 1 & 1 \\
\hline SADC (1992) & 0 & 0 & $1(1992)$ & 0 & 0 & $1(1992)$ \\
\hline COMESA (1994) & 0 & 0 & $1(1994)$ & 0 & 0 & $1(1994)$ \\
\hline EAC & 0 & 0 & 0 & 0 & 0 & 0 \\
\hline SACU $(1969,1992)$ & 0 & 0 & 0 & 3 & 3 & $\begin{array}{l}3 \\
2\end{array}$ \\
\hline CEMAC (1999) & 0 & 0 & $1(1999)$ & 0 & 0 & (from 1998) \\
\hline & & & & & & $\begin{array}{c}1 \\
(1994)\end{array}$ \\
\hline $\begin{array}{l}\text { WAEMU } \\
(1994,2000)\end{array}$ & 0 & 0 & 0 & 0 & 0 & $\begin{array}{c}2 \\
(2000) \\
1(1995)\end{array}$ \\
\hline SAARC (1985) & & 0 & 0 & 0 & 0 & $2(2005)$ \\
\hline GCC (1981) & 0 & 0 & 0 & 0 & $1(1981)$ & $2(2003)$ \\
\hline CACM (1991) & 0 & 0 & 0 & 0 & 0 & $2(1993)$ \\
\hline
\end{tabular}

Source: Te Velde (2006); years between parentheses indicate when certain provisions were announced. Notes: ANDEAN Andean Community of Nations; NAFTA North American Free Trade Agreement; MERCOSUR Mercado Común del Sur; CARICOM Caribbean Community; ANDEAN Andean Community of Nations; ASEAN Association of Southeast Asian Nations; SADC Southern African Development Community; COMESA Common Market of Eastern and Southern Africa; EAC East African Community; SACU Southern African Customs Union; CEMAC Economic and Monetary Community of Central Africa; UEMOA/WAEMU West African Economic and Monetary Union; SAARC South Asian Association for Regional Cooperation; GCC Cooperation Council for the Arab States of the Gulf; CACM Central American Common Market.

Investment Index $=0$ if not member of group

$=1$ if some investment provisions in region (as in COMESA, SADC),

$=2$ if advanced investment provisions in region (e.g. improved investor protection in ASEAN)

$=3$ if complete investment provisions in region (e.g. Chapter XI of NAFTA)

$=-1$ if more restrictive provisions (restrictions on foreign investors in ANDEAN in 70s)

Trade Index $\quad=0$ if not member of group

$=1$ if some trade provisions (e.g. tariff preferences),

$=2$ if low MFN tariffs, (close to) zero intra-reg tariffs

$=3$ if high MFN tariffs, (close to) zero intra-reg tariffs 


\section{Measuring and describing regional integration at the macro level}

A key challenge for any quantitative analysis of the effects of regional integration is to "measure" regional integration. There are at least three broad aspects of regions that need measuring: narrow integration, deep integration and functional co-operation. Measuring is easiest for narrow integration (level of intraregional tariffs), followed by deeper integration (e.g. adoption of common rules on investment) and then functional co-operation (e.g. presence of regional development finance institutions). Table 1 below measures regional integration on trade and investment rules extending the measures in Te Velde (2006).

There are several stages in the regional economic integration process, ranging from the formation of a trade bloc to the establishment of an economic and monetary union. One important step in the integration process is the formation of a customs

Table 2. Summary of key characteristics of regions

\begin{tabular}{|c|c|c|c|c|}
\hline & $\begin{array}{l}\text { Members } \\
\text { (considered, in } \\
\text { 2006) }\end{array}$ & $\begin{array}{l}\text { Level of integration, } \\
\text { current and planned }\end{array}$ & $\begin{array}{l}\text { Intra-regional } \\
\text { trade }(2006)\end{array}$ & $\begin{array}{l}\text { GDP } \\
\text { (bn USD, } \\
\text { 2006) }\end{array}$ \\
\hline EAC & $\begin{array}{l}3 \text { (Rwanda and } \\
\text { Burundi have } \\
\text { joined) }\end{array}$ & $\begin{array}{l}\text { CU operational from } 2005 \\
\text { Common market by } 2012\end{array}$ & 12.8 & 43.3 \\
\hline CEMAC & 5 & $\begin{array}{l}\text { UDEAC CET in } 1994 \\
\text { Full FTA, customs union and } \\
\text { common market planned }\end{array}$ & 1.9 & 44.5 \\
\hline WAEMU & 8 & CU since 2000 & 10.7 & 49.4 \\
\hline COMESA & 20 & $\begin{array}{c}\text { Free trade area by } 2000, \mathrm{CU} \\
\text { planned by } 2008\end{array}$ & 4.0 & 331 \\
\hline SADC & 15 & $\begin{array}{c}\text { Free trade area by } 2008, \mathrm{CU} \\
\text { planned by } 2010\end{array}$ & 7.7 & 380 \\
\hline SACU & 5 & New CET agreed by 2002 & & 276 \\
\hline MERCOSUR & 4 & Customs union & 16.2 & 2160 \\
\hline CARICOM & 15 & Customs union & 9.6 & 62.7 \\
\hline NAFTA & 3 & No & 43.8 & 15300 \\
\hline ANDEAN & 4 & Customs union & 9.6 & 281 \\
\hline ASEAN & 10 & No & 24.1 & 1040 \\
\hline SAARC & 7 & No & 5.4 & 1140 \\
\hline
\end{tabular}

Notes: ANDEAN Andean Community of Nations; NAFTA North American Free Trade Agreement; MERCOSUR Mercado Común del Sur; CARICOM Caribbean Community; ANDEAN Andean Community of Nations; ASEAN Association of Southeast Asian Nations; SADC Southern African Development Community; COMESA Common Market of Eastern and Southern Africa; EAC East African Community; SACU Southern African Customs Union; CEMAC Economic and Monetary Community of Central Africa; UEMOA/WAEMU West African Economic and Monetary Union; SAARC South Asian Association for Regional Cooperation. 
union which not only eliminates tariffs and quotas on trade between member countries, but also establishes a common external tariff applying to non-members. In Africa, the four major customs unions are divided by region and include the East African Community (EAC), the Economic and Monetary Community of Central Africa (CEMAC), the South African Customs Union (SACU), and the West African Economic and Monetary Union (WAEMU). Just under half of Africa's fifty three nations are members of a customs union, making these partnerships an important part of the economic and political landscape. The members in WAEMU and in CEMAC share a common currency, and were formed after the devaluation of the CFA franc in 1994. The South African Customs Union is the oldest group dating back to 1910, although it has been altered under revision agreements in 1969 and 1994. One recent customs union to form is the EAC after the collapse of a similar group in 1977. But many more are being planned, see Table 2 .

Table 3. Sub-regional development finance institutions

\begin{tabular}{lcccc}
\hline & $\begin{array}{c}\text { Presence and name of } \\
\text { Sub-regional DFI }\end{array}$ & $\begin{array}{c}\text { Exposures - } \\
\text { loan portfolio } \\
\text { (USD mn) }\end{array}$ & $\begin{array}{c}\text { Regional GDP } \\
\text { (USD mn) }\end{array}$ & Exposure / GDP \\
\hline MERCOSUR & No & & 74840 & 0.009 \\
CARICOM & CDB & 4188 & 162711 & 0.026 \\
ANDEAN & CAN & & & \\
ASEAN & No & & & \\
SADC & No & 179 & 46512 & \\
COMESA & No & & & \\
EAC & EADB & & & \\
SACU & No & 1953 & 28465 & 0.069 \\
SADC & No & & & \\
CEMAC & No & 4538 & 108616 & 0.042 \\
WAEMU & BOAD & & \\
SAARC & No & & & \\
CACM & CABEI & & & \\
GCC & No & & & \\
\hline
\end{tabular}

Source: annual reports of DFIs;

Notes: ANDEAN Andean Community of Nations; NAFTA North American Free Trade Agreement; MERCOSUR Mercado Común del Sur; CARICOM Caribbean Community; ANDEAN Andean Community of Nations; ASEAN Association of Southeast Asian Nations; SADC Southern African Development Community; COMESA Common Market of Eastern and Southern Africa; EAC East African Community; SACU Southern African Customs Union; CEMAC Economic and Monetary Community of Central Africa; UEMOA West African Economic and Monetary Union; SAARC South Asian Association for Regional Cooperation; GCC Cooperation Council for the Arab States of the Gulf; CACM Central American Common Market. 
Table 4. Development of economic performance of regions over time (last decade)

\begin{tabular}{|c|c|c|c|c|c|}
\hline & $\begin{array}{c}\text { Convergence } \\
(\text { sigma }) \\
(1997-2006)\end{array}$ & $\begin{array}{l}\text { Did export/ } \\
\text { GDP increase } \\
\text { (1997-2006) }\end{array}$ & $\begin{array}{c}\text { Did FDI } \\
\text { stock /GDP } \\
\text { increase } \\
(1997-2006)\end{array}$ & $\begin{array}{l}\text { Did intra- } \\
\text { regional } \\
\text { trade increase }\end{array}$ & $\begin{array}{c}\text { Did regional FDI } \\
\text { as \% of develop- } \\
\text { ing country FDI } \\
\text { increase? } \\
(1997-2006)\end{array}$ \\
\hline EAC & $\sqrt{ }$ & $\sqrt{ }$ & $\sqrt{ }$ & - & $\sqrt{ }$ \\
\hline CEMAC & - & $\sqrt{ }$ & $\sqrt{ }$ & - & $\sqrt{ }$ \\
\hline WAEMU & - & - & - & $\sqrt{ }$ & - \\
\hline COMESA & - & $\sqrt{ }$ & $\sqrt{ }$ & - & $\sqrt{ }$ \\
\hline SADC & - & $\sqrt{ }$ & $\sqrt{ }$ & & $\sqrt{ }$ \\
\hline SACU & - & $\sqrt{ }$ & $\sqrt{ }$ & & $\sqrt{ }$ \\
\hline MERCOSUR & - & $\sqrt{ }$ & $\sqrt{ }$ & - & - \\
\hline CARICOM & - & $\sqrt{ }$ & $\sqrt{ }$ & - & $\sqrt{ }$ \\
\hline NAFTA & - & - & $\sqrt{ }$ & $\sqrt{ }$ & $\mathrm{Na}$ \\
\hline ANDEAN & - & $\sqrt{ }$ & $\sqrt{ }$ & - & - \\
\hline ASEAN & $\sqrt{ }$ & $\sqrt{ }$ & $\sqrt{ }$ & $\sqrt{ }$ & - \\
\hline SAARC & - & $\sqrt{ }$ & $\sqrt{ }$ & $\sqrt{ }$ & $\sqrt{ }$ \\
\hline
\end{tabular}

Notes: ANDEAN Andean Community of Nations; NAFTA North American Free Trade Agreement; MERCOSUR Mercado Común del Sur; CARICOM Caribbean Community; ANDEAN Andean Community of Nations; ASEAN Association of Southeast Asian Nations; SADC Southern African Development Community; COMESA Common Market of Eastern and Southern Africa; EAC East African Community; SACU Southern African Customs Union; CEMAC Economic and Monetary Community of Central Africa; UEMOA West African Economic and Monetary Union; SAARC South Asian Association for Regional Cooperation; GCC Cooperation Council for the Arab States of the Gulf; CACM Central American Common Market.

Measurement of regions goes beyond narrow and deep trade integration and should also cover functional co-operation. Table 3 below shows one example of functional regional co-operation. It highlights whether a region has established a sub-regional development finance institution specifically aimed at providing finance to that region. There are five such regions, and the final column measures the total size of the portfolio of loans/finance outstanding as a ratio to regional GDP.

Table 4 provides recent performance of regions with respect to trade, FDI and convergence. It is important to note that nearly all regions experienced an increase in exports and FDI. Meyn and Te Velde (2008) argue that regional integration itself has helped promote trade and FDI. 


\section{Growth and convergence}

Two types of convergence are normally tested in empirical research.

- $\beta$ convergence is tested for to determine whether or not poor countries are growing faster than richer countries (a negative correlation between initial per capita income and growth in per capita income);

- $\sigma$ convergence tests whether or not the dispersion between per capita income levels declines over time.

We examine unconditional and conditional $\beta$ convergence across a number of developing countries. Unconditional $\beta$ convergence, which disregards all other possible impacts on growth, suggests that overtime countries with differing levels of initial GDP per capita will converge with one another over the long run. However, in practice we do not seem to observe this strict adherence to growth and convergence paths as emphasized in the traditional growth literature. Researchers have begun to test growth models by looking at particular groups of countries and regions. For example, do developing countries growth rates converge with one another in a region? And does joining a customs union result in growth and enhanced convergence?

We can use standard growth models and test for unconditional $\beta$ convergence by estimating

$$
g_{i t}=\alpha+\beta Y_{0}+\varepsilon_{i t}
$$

Where $g_{i t}$ is the first difference of real per-capita GDP, it is therefore the growth rate; and $Y_{\mathrm{o}}$ is the logarithm of the initial level of real GDP per-capita. The subscripts $i$ and $t$ represent countries and time respectively. As stated above, for the first approach $t$ is annual data, but it also possible to use $t$ as time periods. The null hypothesis of convergence is accepted if $\beta$ is negative, so that countries with lower initial values of GDP per capita should have higher growth rates.

To test for conditional convergence we estimate:

$$
g_{i t}=\alpha+\beta Y_{0}+\delta X_{i t}+\varepsilon_{i t}
$$

Where the vector $X$ contains other explanatory variables such as population, trade and gross capital fixed formation (these as \% of GDP and then logged). The data come from World Development Indicators. The null hypothesis of (conditional) convergence is accepted if $\beta$ is negative and significant. We estimate 
econometric models to tests for unconditional convergence. We also include measures of regions to isolate the effects of regions on growth. The regions are defined by membership of a Customs Union (CU) or Free Trade Area (FTA).

Whether regional integration has promoted convergence or divergence among its members is disputed. For example, Ghura and Hadjimichael (1996) found a tendency of per capita income convergence growing by $2 \%$ when investigating 29 Sub-Saharan African countries belonging to regional integration schemes. In the case of the old EAC (1960-77), Venables (1999) argues that Kenya moved its production structure in the opposite direction as it would have done under free market conditions. Only under the protection of the EAC, Kenya was able to expand its manufacturing production - at the expense of the poorer countries, which had to shift their manufacturing imports from the Rest of the World towards Kenya. The losing countries, Tanzania and Uganda, could not benefit from trade creation since their limited product range was also produced by Kenyan producers in a more competitive way.

Based on an econometric analysis using data from 46 African countries Hammouda et al. (2007) assessed the level and rate of the convergence of income for the members of SADC, COMESA, ECOWAS, CEMAC and UEMOA. They found that the link between regional integration and income convergence is low for which they classified three main reasons. First, the slow growth of output, productivity and accumulation of production factors; second, the low levels of intraregional trade, the bias towards commodity trade and the low factor mobility; and third, the limited inflow of FDI which further constrained capital accumulation.

Other studies find conflicting evidence based on time periods and methods used. Studies have found convergence in SADC over 1960-2000 (Holmes, 2005), no convergence in ECOWAS over 1960-2000 (Holmes, 2005), convergence in ECOWAS over 1960-1990 (Jones, 2002), no convergence in COMESA over 19802002 (Carmignani, 2006), convergence in COMESA over 1995-2004 (Mutoti and Kihangiri, 2006), limited convergence across UEMOA, 1990-2003 (Van de Boogaerde and Tsangarides, 2005); and convergence across UEMOA, 1965-2002 (Aziz Wane, 2004).

The methods used are either statistical (describing income levels) or econometric (using standard growth models). The studies discuss the following factors behind convergence and divergence of incomes within regions: the size of the group does not matter (Holmes, 2005); integration of monetary policy, harmonisation policy, different institutions and trading rules (Carmignani, 2006); labour mobility (Van de 
Boogaerde and Tsangarides, 2005; Konseiga, 2005); macro economic convergence (Rossouw, 2006); and competitive advantage (Venables, 2003).

\section{Measuring and explaining dispersion of incomes}

Researchers have also been interested in $\sigma$ convergence, testing whether or not the dispersion amongst per capita income levels in the region declines over time.

$$
\Delta \sigma_{i t}=\alpha+\beta \sigma_{i 0}+\gamma X_{i t}+\varepsilon_{i t}
$$

Where $\sigma$ is the standard deviation in real per capita incomes ( $\mathrm{t}$ is time; 0 is initial period), and $X$ is a set of explanatory variables including measures describing the type of region, which varies across regions and in some cases over time. This could include regional infrastructure, regional cohesion policies, intra-regional trade and migration or income levels. There are of course different ways of describing the variability of incomes in a region.

\section{Regional constraints in growth diagnostics}

The Hausmann-Rodrik-Velasco growth diagnostics framework is one approach aimed at identifying the binding constraint to growth. The framework focuses on two key factors behind growth: the return to investment; and the cost of financing that investment. Faster growth involves higher private returns to investment than the costs of financing it. Private returns depend both on the returns to investment, and the appropriability of those returns by the investor. In its simplest form, if the cost of borrowing is high but borrowing is also high, it suggests profitable investment opportunities exist, but private investors are credit constrained and hence the cost of financing is the problem. On the other hand, if the cost of finance is not excessive, but borrowing is low, the constraint to growth is not the cost of financing, but low returns to investment. These options - cost of finance, or low return to investment - can be represented in a tree structure.

The framework can then be used to move along the tree structure to find the binding constraint. For instance, high cost of financing can be due to limited access to international capital or weak domestic capital markets. Low returns to investment can be due to low economic returns (e.g. due to poor infrastructure, weak labour markets, market failures, regulatory constraints etc.) or whether the ability of the investor to appropriate these returns is the problem (e.g. due to macroeconomic risks, insecure property rights, high taxes, regulatory uncertainty, 
corruption etc.). It is likely that growth diagnostics e.g. for landlocked countries, find that regional infrastructure is a key, if not binding, constraint to growth.

\section{B. Growth analytical techniques at the Micro level}

Several researchers have shown that regional integration leads to faster trade, especially intra-regional trade. ${ }^{1}$ They have also shown that (deeper) regional integration attracts FDI. ${ }^{2}$ While trade and FDI can lead to improved allocative efficiency, authors emphasise dynamic effects. The dynamic effects of FDI and trade can be tested at the macro level, using growth regressions. However, a more direct way of testing dynamic effects is by using firm level data and examining whether regional trade and FDI (which researchers have shown to be promoted by regional integration in the case of several regions) affects productivity of the firm. Exporting and ownership ${ }^{3}$ is associated with higher productivity, but how does is productivity affected by regional integration.

We build on the results of background research for Qureshi and Te Velde (2007). To examine firm performance, they use a simple Cobb-Douglas production function which links output with inputs and the firm's productivity, as follows:

$$
y_{i}=\alpha_{0}+\alpha_{L} L_{i}+\alpha_{K} K_{i}+\varepsilon_{i},
$$

where $y_{\mathrm{i}}$ is $\log$ of output measured in value added terms of firm $i$, and $L$ and $K$ are logs of labour and capital inputs, respectively. $\mathcal{E}_{\mathrm{i}}$ is the unobserved error term that represents the log of the productivity shock or total factor productivity $(T F P)$ of firm $i$ and captures any effects in total output not caused by inputs or productivity. Some suggest that TFP estimated in this way suffers from a simultaneity bias as TFP shocks and inputs move together.

Olley and Pakes (1996) propose to overcome the simultaneity problem by using

${ }^{1}$ Frankel (1997) found that the regional integration raised intra-regional trade by $65 \%$ in the EC and $150 \%$ in Mercosur and Andean. Frankel and Rose (2001) show that RTAs have a big average effect on intraregional trade. Soloaga and Winters (2001) show that the effects can differ amongst RTAs, with some positive and others negative effects. They show that the new wave of regionalism in the 1990s (new blocks and revamping of old blocks) has not led to further intra-regional trade. Further, they show that only the EU and EFTA may have led to trade diversion and the other blocks to trade creation. ${ }^{2}$ Te Velde and Bezemer (2006) and Levy et al. (2002) find that regional integration leads to extra-regional FDI and in some case intra-regional FDI.

${ }^{3}$ A significant body of evidence (e.g. Haddad and Harrison, 1993; Aitken and Harrison, 1999; Djankov and Hoekman, 2000) finds that the productivity level of foreign firms is higher than in domestic firms although but that the effects on productivity levels and growth in domestic firms are mixed. 
the firm's investment decision to proxy unobserved productivity shocks. Their technique, later modified by Levinsohn and Petrin (2003), is commonly used to obtain consistent estimates of the production function. ${ }^{4}$ They divide $\varepsilon$ in into two components, $\eta$ which is a part of the productivity shock that influences a firm's decisions relating to factor inputs, and $\xi$ which is an independent and identically distributed random component. $L$ and $K$ are treated as free and state variables, respectively, and investment is defined as a function of $K$ and $\eta$. This gives us:

$$
y_{i}=\alpha_{0}+\alpha_{L} L_{i}+\alpha_{K} K_{i}+\eta\left(I_{i}, K_{i}\right)+\xi_{i}
$$

Now defining $\varphi\left(I_{i}, K_{i}\right)=\alpha_{0}+\alpha_{K} K_{i}+\eta\left(I_{i}, K_{i}\right)$, we obtain:

$$
y_{i}=\alpha_{L} L_{i}+\varphi\left(I_{i}, K_{i}\right)+\xi_{i}
$$

A first stage estimator that is linear in $L$ and non-parametric in $\varphi$ is used to obtain a consistent estimate of $\alpha_{\mathrm{L}}{ }^{5}$. To identify $\alpha_{\mathrm{K}}$, two assumptions are made. First, $\eta$ follows a first-order Markov process and, second, $K$ does not respond immediately to $\psi$, defined as the innovations in productivity over last period's expectation, that is, $\psi_{i t}=\eta_{i t}-E\left[\eta_{i t} \mid \eta_{i t-1}\right]$. Putting $\psi$ in (5) and defining $y^{*}$ as output net of labour's contribution, we get:

$$
y_{i}^{*}=y_{i}-\alpha_{L} L_{i}=\alpha_{0}+\alpha_{K} K_{i}+E\left[\eta_{i t} \mid \eta_{i t}\right]+\xi_{i}^{*},
$$

where $\xi_{i}^{*}=\psi_{i}+\xi_{i}$. Since $\psi$ and $\xi$ are both uncorrelated with $K$, regressing $y^{*}$ on $K$ and $\mathrm{E}\left[\eta_{\mathrm{t}} \mid \eta_{\mathrm{t}-1}\right]$ produces a consistent estimate of $\alpha_{\mathrm{K}}$. Having obtained consistent estimates for both parameters of interest, $\alpha_{\mathrm{L}}$ and $\alpha_{\mathrm{K}}$, we can construct the individual error term $\varepsilon_{\mathrm{i}}$ from (4) which will give us unbiased estimates of TFP.

To examine the effect of regional integration on firm performance we estimate TFP using Levinsohn and Petrin and estimate the effect of exporting and foreign ownership (to and from the region, and to and from outside the region) and other characteristics of the firm $(F)$ and others characteristics $(X)$, and estimate:

\footnotetext{
${ }^{4}$ Levinsohn and Petrin (2003) use intermediate inputs, such as material inputs, as a proxy instead of investment. This is because most datasets contain significantly less zero-observations in materials than in firm-level investment.

${ }^{5}$ Olley and Pakes (1996) employ a fourth-order polynomial in $I$ and $K$ to approximate $\varphi($.), estimating (2) using OLS, with output regressed on labour and the polynomial terms.
} 


$$
\log \left(T F \mathrm{P}_{i}\right)=\beta_{0}+\beta_{S} E X P_{i, \text { region }}+\beta_{S} E X P_{i, \text { outsideregion }}+\sum_{k} \beta_{F_{k}} F_{i k}+\sum_{j} \beta_{X_{j}} X_{j k}+v_{i},
$$

where $v_{\mathrm{i}}$ is a white noise error term, $F$ includes firm characteristics such as the age, size and ownership of the firm, and $X$ comprises a number of other factors. EXP is a $0 / 1$ dummy on whether the main exports of the firm is to the region or to outside the region.

\section{Regional Integration, Growth and Convergence: Empirical Results}

\section{A. Macro growth effects of regional integration}

Table 5 presents the regression results or the growth models as explained in equation (2) for a panel of nearly 100 developing countries (see appendix) over 1970-2004. We estimate 7 different growth models and test for the effects of regional integration measures. Model 1 regresses changes in GDP per capita on the level of GDP per capita (lagged) and a number of other variables such as trade, FDI, fixed capital investment and population growth. All variables have the expected sign and are significant. Because the coefficient on lagged GDP per capita is negative and significant, this model provides evidence for conditional convergence.

Model 2 includes separate regional dummies. It shows that growth experiences differ significantly across regions, in that some regions are related to faster growth. Model 3 introduces dummies for Customs Unions (when a country was part of $\mathrm{CU})$. The model estimations suggest that there are no clear growth effects of CUs, even when accounting for idiosyncratic regional growth experiences (model 4).

Models 5-7 include the trade provisions index discussed previously. Again, this does not show clear growth effects, with or without time dummies and additional explanatory variables. Thus, it is hard to find growth effects of regional integration at this level of analysis and using the present way of measuring regions, which is consistent with the findings of authors such as Vamvakidis (1998). It may not come as a complete surprise because all regions differ and the growth effects depend on a host of factors, and growth generally depends on lots of other factors.

Whilst regional integration itself may not be associated with faster growth at the macro level (when accounting for other factors such as trade and investment), there are positive effects through the effects of regional integration on trade and 
Table 5. Regional integration and growth

\begin{tabular}{|c|c|c|c|c|c|c|c|c|c|c|c|c|c|c|}
\hline & \multicolumn{2}{|c|}{ Model 1} & \multicolumn{2}{|c|}{ Model 2} & \multicolumn{2}{|c|}{ Model 3} & \multicolumn{2}{|c|}{ Model 4} & \multicolumn{2}{|c|}{ Model 5} & \multicolumn{2}{|c|}{ Model 6} & \multicolumn{2}{|c|}{ Model 7} \\
\hline & Coef. & t-stat & Coef. & t-stat & Coef. & t-stat & Coef. & t-stat & Coef. & t-stat & Coef. & t-stat & Coef. & t-stat \\
\hline (ln) Initial per capita GDP & -0.006 & -4.880 & -0.007 & -5.310 & -0.007 & -4.930 & -0.007 & -5.340 & -0.007 & -5.420 & 0.000 & -0.120 & -0.008 & -6.000 \\
\hline (ln) FDI as $\%$ of GDP & 0.003 & 4.120 & 0.003 & 4.300 & 0.003 & 4.190 & 0.003 & 4.250 & 0.003 & 4.460 & & & 0.003 & 4.770 \\
\hline (ln) Inv as $\%$ of GDP & 0.034 & 9.000 & 0.034 & 8.970 & 0.034 & 8.600 & 0.034 & 8.930 & 0.034 & 8.960 & & & 0.034 & 9.010 \\
\hline Population growth & -0.009 & -3.850 & -0.008 & -3.030 & -0.008 & -3.240 & -0.008 & -3.040 & -0.008 & -3.090 & -0.007 & -2.620 & -0.010 & -3.760 \\
\hline \multicolumn{15}{|l|}{$\begin{array}{l}\text { Regional dummies } \\
\text { (geographically based) }\end{array}$} \\
\hline Gcc & & & 0.027 & 3.780 & & & 0.027 & 3.770 & 0.030 & 4.050 & -0.017 & -1.830 & 0.031 & 4.040 \\
\hline Eac & & & 0.004 & 0.700 & & & 0.005 & 0.770 & 0.004 & 0.740 & -0.009 & -1.760 & 0.006 & 0.950 \\
\hline Cemac & & & -0.001 & -0.080 & & & -0.001 & -0.070 & 0.001 & 0.070 & -0.012 & -2.000 & -0.001 & -0.110 \\
\hline Waemu & & & -0.007 & -1.780 & & & -0.010 & -1.900 & -0.006 & -1.300 & -0.019 & -4.850 & -0.005 & -1.240 \\
\hline Cacm & & & 0.001 & 0.240 & & & 0.001 & 0.260 & 0.003 & 0.750 & -0.017 & -3.830 & 0.001 & 0.300 \\
\hline Sacu & & & 0.003 & 0.580 & & & 0.003 & 0.610 & 0.010 & 1.440 & 0.004 & 0.600 & 0.000 & 0.020 \\
\hline $\begin{array}{l}\text { Regional Integration } \\
\text { dummies ( } 1 \text { from year } \\
\text { when region formed) }\end{array}$ & & & & & & & & & & & & & & \\
\hline
\end{tabular}


Table 5. Regional integration and growth (continued)

\begin{tabular}{|c|c|c|c|c|c|c|c|c|c|c|c|c|c|c|}
\hline & \multicolumn{2}{|c|}{ Model 1} & \multicolumn{2}{|c|}{ Model 2} & \multicolumn{2}{|c|}{ Model 3} & \multicolumn{2}{|c|}{ Model 4} & \multicolumn{2}{|c|}{ Model 5} & \multicolumn{2}{|c|}{ Model 6} & \multicolumn{2}{|c|}{ Model 7} \\
\hline & Coef. & t-stat & Coef. & t-stat & Coef. & t-stat & Coef. & t-stat & Coef. & t-stat & Coef. & t-stat & Coef. & t-stat \\
\hline GCC & & & & & 0.025 & 3.560 & & & & & & & & \\
\hline EAC & & & & & -0.003 & -0.470 & -0.009 & -0.960 & & & & & & \\
\hline CEMAC & & & & & 0.001 & 0.090 & 0.001 & 0.060 & & & & & & \\
\hline WAEMU & & & & & -0.001 & -0.210 & 0.007 & 0.940 & & & & & & \\
\hline CAN & & & & & -0.001 & -0.360 & & & & & & & & \\
\hline CARICOM & & & & & 0.006 & 0.920 & 0.016 & 1.420 & & & & & & \\
\hline MERCOSUR & & & & & -0.002 & -0.260 & -0.010 & -1.170 & & & & & & \\
\hline CACM & & & & & 0.001 & 0.280 & & & & & & & & \\
\hline SACU & & & & & 0.003 & 0.710 & & & & & & & & \\
\hline $\begin{array}{l}\text { Regional trade } \\
\text { provisions index }\end{array}$ & & & & & & & & & -0.002 & -1.410 & 0.003 & 1.420 & 0.001 & 0.800 \\
\hline Time dummies & & & & & & & & & & & Yes & & Yes & \\
\hline Constant & -0.111 & -6.140 & -0.101 & -4.920 & -0.111 & -5.950 & -0.102 & -4.930 & -0.102 & -4.950 & 0.038 & 4.260 & -0.108 & -5.130 \\
\hline $\mathrm{R}-2$ & & 0.127 & & 0.133 & & 0.130 & & 0.135 & & 0.134 & & 0.064 & & 0.190 \\
\hline No obs & & 1992 & & 1992 & & 1992 & & 1992 & & 1992 & & 2934 & & 1992 \\
\hline
\end{tabular}

Notes: ANDEAN Andean Community of Nations; NAFTA North American Free Trade Agreement; MERCOSUR Mercado Común del Sur; CARICOM Caribbean Community; ANDEAN Andean Community of Nations; ASEAN Association of Southeast Asian Nations; SADC Southern African Development Community; COMESA Common Market of Eastern and Southern Africa; EAC East African Community; SACU Southern African Customs Union; CEMAC Economic and Monetary Community of Central Africa; UEMOA West African Economic and Monetary Union; SAARC South Asian Association for Regional Cooperation; GCC Cooperation Council for the Arab States of the Gulf; CACM Central American Common Market.

Estimated standard errors are robust standard errors. 
investment. Because we find that trade and FDI promote growth, and as regional integration tends to increase trade and FDI (this is well documented in the literature, see e.g. Meyn and Te Velde, 2008), regional integration will still have a positive impact on growth in its members through the effects of increased trade and investment on growth.

\section{B. Explaining Convergence within Regions}

Figure 1 shows developments in the disparities of incomes in selected regions. On this measure, only the incomes of members of EAC and ASEAN have converged over the past decade although over the longer-run WAEMU and SACU have also converged somewhat.

Table 6 presents the estimation results for explaining divergence and convergence within regions. Our study is hampered by the lack of good measures

Figure 1. Dispersion of incomes, by region

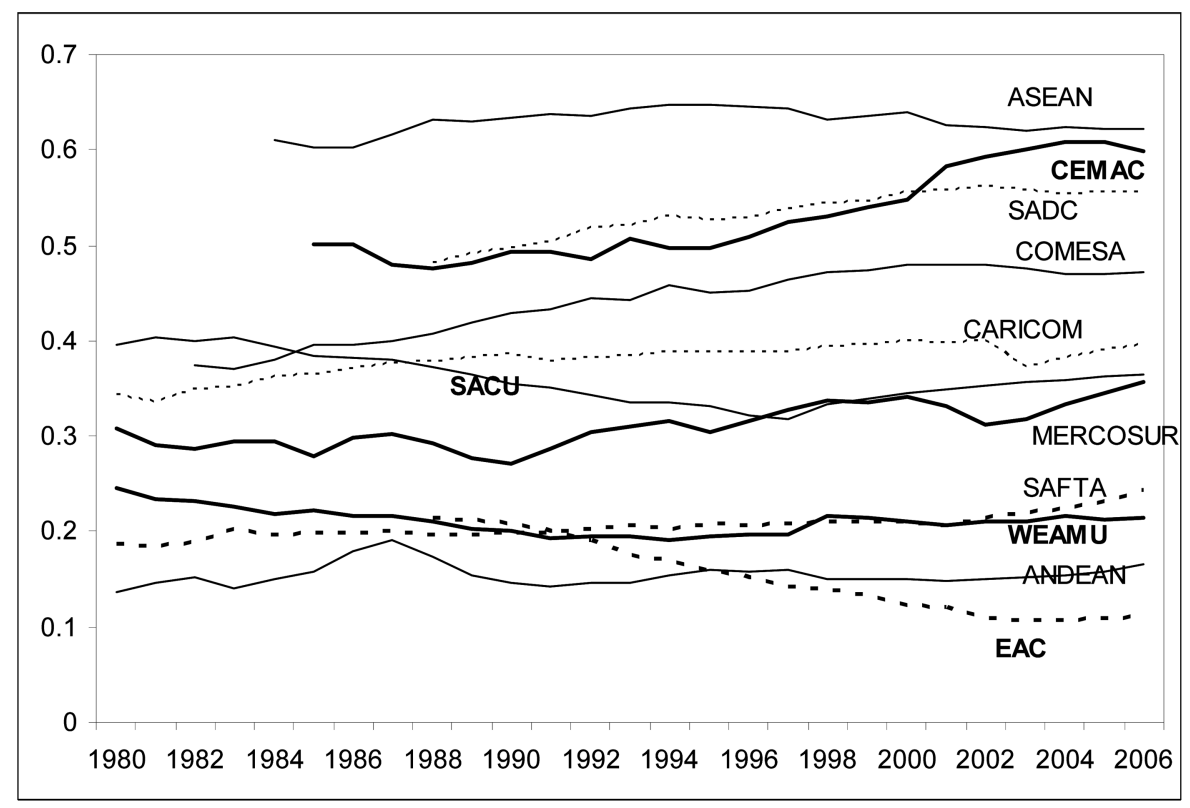

Notes: ANDEAN Andean Community of Nations; NAFTA North American Free Trade Agreement; MERCOSUR Mercado Común del Sur; CARICOM Caribbean Community; ANDEAN Andean Community of Nations; ASEAN Association of Southeast Asian Nations; SADC Southern African Development Community; COMESA Common Market of Eastern and Southern Africa; EAC East African Community; SACU Southern African Customs Union; CEMAC Economic and Monetary Community of Central Africa; UEMOA West African Economic and Monetary Union; SAARC South Asian Association for Regional Cooperation; GCC Cooperation Council for the Arab States of the Gulf; CACM Central American Common Market. 
Table 6. Explaining changes in convergence of incomes $(\Delta \sigma)$

\begin{tabular}{lcc}
\hline & Coefficient & T-stat \\
\hline$\sigma$ lagged one period & -0.076 & $-2.63^{* * *}$ \\
Development Finance Institutions (loan exposure over regional GDP) & -1.215 & $-2.05^{* *}$ \\
Share intra-regional trade (\% of total) & 0.000 & 0.92 \\
CEMAC & 0.006 & 0.74 \\
WEAMU & 0.055 & $2.03^{* *}$ \\
MERCOSUR & -0.018 & -1.79 \\
CARICOM & -0.002 & -0.56 \\
COMESA & -0.005 & -0.55 \\
EAC & -0.034 & $-2.74^{* * *}$ \\
SAARC & -0.024 & -1.7 \\
Constant & 0.041 & 2.01 \\
Observations & 152 & \\
F-statistic & $6.11^{* * * *}$ & \\
R2 & 0.23 & \\
\hline *** indicate significance at 10\%, 5\% and 1\% levels respectively, the estimated standard errors are robus. \\
Notes: ANDEAN Andean Community of Nations; NAFTA North American Free Trade Agreement; \\
MERCOSUR Mercado Común del Sur; CARICOM Caribbean Community; ANDEAN Andean \\
Community of Nations; ASEAN Association of Southeast Asian Nations; SADC Southern African \\
Development Community; COMESA Common Market of Eastern and Southern Africa; EAC East \\
African Community; SACU Southern African Customs Union; CEMAC Economic and Monetary \\
Community of Central Africa; UEMOA West African Economic and Monetary Union; SAARC South \\
Asian Association for Regional Cooperation; GCC Cooperation Council for the Arab States of the Gulf; \\
CACM Central American Common Market. & \\
\end{tabular}

of the explanatory variables such as intra-regional migration or regional infrastructure. However, it is clear that regions with a higher initial $\sigma$ experience higher decreases in $\sigma$ later on, i.e. the coefficient on $\sigma$ in Table 6 is significant and negative. The level of intra-regional trade and income levels do not explain changes in $\sigma$ (the coefficient is insignificant). However, the presence of a regional DFI with relatively high loan exposure does reduce regional income disparities. A one percentage point increase in DFI exposure will lead to a drop of $\sigma$ of about one percentage point (the coefficient is -1.2).

\section{Regional integration and Growth diagnostics}

It is important to supplement the above quantitative macro level analysis with micro level and more qualitative accounts. For example, the World Bank's country economic memorandum (World Bank, 2008; p. 126) undertakes a growth diagnostic for Uganda. It concludes the following factors are binding constraints: under-investment in infrastructure is the binding constraint to growth in Uganda; 
electricity is the number one priority - with major investments needed in towns outside of Kampala to expand job creation; trunk roads and main roads around Kampala need to be better maintained and expanded at key bottlenecks; the costs of power and fuel are too high; financial intermediation is a future constraint that could quickly bind if infrastructure constraints are removed; and coordination gaps are leading to inefficiencies in infrastructure, and seemingly skills training.

Most of these key growth constraints have a regional dimension. There have been various studies examining the economic rates of return on infrastructure projects concluding that these rates tend to be high - but a regional functional approach is often needed to realise the gains. For example, there is at present a severe shortage of electricity-generating capacity in Uganda. This could have been overcome through the use of effective regional electricity grids. Instead, to overcome these shortages, Uganda currently imports oil using pipelines from Kenya.

There are also regional constraints to further rail transport. Uganda's imports and exports make heavy use of the port in neighbouring Mombassa. The UgandaKenya railways operate under a private franchisee which needs more effective regional approaches towards safeguarding a stable investment environment in order to stimulate more investment. The rail link was broken at the time of conflict in Kenya a few years ago with large effects for Uganda.

Finally, road connections are poor, including in a regional context. Selassie (2008) records an impressive increase in manufactured exports to regional markets in Rwanda, Sudan and DRC which have risen over the past decade from zero due to conflict to over US\$20 million per month in 2006. With better roads and other transportation links, even more exports would be possible.

Thus a quick review of the binding constraints to growth reveal that many have a regional dimension and that more and better regional integration could be helpful.

\section{Micro Effects of Regional Integration}

We use the estimation results for the production function using Levinsohn-Petrin techniques as provided in Qureshi and Te Velde (2007) and derive TFP measures which are then used as the endogenous variable in Table 7. We examine whether exporting firms have higher productivity, and whether the destination of exporting matters. Narrow and deep integration increase regional exports (as well as imports) as has been shown in the empirical literature (Meyn and Te Velde, 2008).

Regressions for Benin, Malawi (to a lesser extent) and South Africa indicate that exporting firms have higher productivity than other firms. The present regressions 
Table 7. Explaining firm level productivity

\begin{tabular}{lccccc}
\hline & Benin (1) & Benin (2) & Malawi (1) & Malawi (2) & South Africa \\
\hline Age & 0.005 & 0.005 & 0.013 & 0.012 & 0.014 \\
& $(1.04)$ & $(1.04)$ & $(2.19)^{* *}$ & $(2.27)^{* *}$ & $(5.64)^{* * *}$ \\
Size (employment) & -0.000 & -0.02 & 0.001 & 0.001 & 0.001 \\
& $(-0.26)$ & $(-0.34)$ & $(3.40)^{* * *}$ & $(3.35)^{* * * *}$ & $(4.83)^{* * *}$ \\
Foreign ownership status & 0.003 & 0.003 & 0.006 & 0.007 & 0.58 \\
& $(0.95)$ & $(0.93)$ & $(2.23)^{* *}$ & $(2.61)^{* *}$ & $(4.09)^{* * *}$ \\
Exporting status & & 0.74 & & 0.32 & \\
Main export to region & 0.67 & $(2.23)^{* *}$ & & $(1.43)$ & \\
$\quad$ (UEMOA/SADC) & $(1.78)^{*}$ & & 0.46 & & 0.65 \\
Main export to outside & 0.77 & & $(1.65)^{*}$ & & $(4.47)^{* * *}$ \\
$\quad$ region & $(2.28)^{* *}$ & & 0.16 & & 0.50 \\
Constant & 1.79 & 1.79 & 4.03 & 4.04 & 7.02 \\
& $(15.4)^{* * *}$ & $(15.7)^{* * *}$ & $(24.3)^{* * *}$ & $(24.3)^{* * *}$ & $(89.2)^{* * *}$ \\
\hline Observations & 118 & 118 & 128 & 128 & 405 \\
F-statistic & $2.08^{* *}$ & $2.36^{* *}$ & $10.45^{* * *}$ & $13.04^{* * *}$ & $43.99^{* * *}$ \\
F-test (coeff region & 0.16 & & 1.06 & & $15.4^{* * * *}$ \\
$\quad$ = coeff outside region) & & & & & 0.39 \\
$\mathrm{R}^{2}$ & 0.10 & 0.10 & 0.15 & 0.15 & \\
\hline
\end{tabular}

Notes: Dependent variable in all specifications is log of total factor productivity obtained from the levinsohn petrin technique; *,**,*** indicate significance at $10 \%, 5 \%$ and $1 \%$ levels respectively, the estimated standard errors are robust.

Data from World Bank Enterprise Surveys used by Qureshi and Te Velde (2007).

cannot be used to argue whether high productivity firms become exporters or whether exporting firms become high productivity firms because we did not have access to panel data.

We then distinguish on whether the main exports of the firm go to the region (e.g. to UEMOA for Benin, and Eastern and/or Southern Africa for Malawi and South Africa) or whether the main exports go outside of the region. The regression results show that exporters to the region and exporters to outside the region are statistically associated with the same levels of productivity - this is because the Ftest on whether the coefficients on region and outsideregion is statistically insignificant. The regressions Benin-2 and Malawi-2 show that exporters are more productive compared to non-exporters and significantly so in Benin. And in the case of Malawi, productivity of regional exporters in actually higher than other exporters. In the case of South Africa, regional exporters are statistically more productive than world-wide exporters, and both are more productive compared to 
domestic firms.

This research therefore complements Schiff and Wang (2003) on the effects of imports in the case of NAFTA. It shows that regional integration can be associated with the same or better levels of integration and hence dynamic effects compared to all other integration. This highlights the presence of dynamic effects of regional integration in Africa, which stands in stark contrast with the low static/allocative macro effects expected from integration of countries with similar production structures as in Africa.

\section{Conclusions}

This note has examined empirically whether and how regional integration leads to convergence and growth amongst developing countries. Using standard growth models for nearly 100 developing countries over 1970-2004 we have not been able to find robust growth effects of regional integration per se at the aggregated level of analysis even after using alternative measures of regional integration. However while regional integration itself is not associated with faster growth at the macro level (when accounting for other factors such as trade and investment), there are positive effects through the effects of regional integration on trade and investment.

We find that trade and FDI promote growth, and because regional integration increases trade and FDI, regional integration will still have a positive impact on growth in its members through the effects of increased trade and investment on growth.

Further, country-specific growth diagnostics do suggest that regional integration can be a key binding constraint to growth as "deep" regional approaches can help to address crucial rail, road, air and energy links amongst countries (e.g. in the EAC). Finally, while the macro-economic literature on regional integration tends to highlight only limited growth effects from African regional integration, our work at the firm level in three African countries (Benin, Malawi and South Africa) is indicative of significant dynamic effects of regional integration through the effects on firm level productivity in Africa.

We also examine convergence of incomes within regions. The findings suggest that initially high levels of regional income disparities are associated with greater decreases in disparities. But whilst the level of intra-regional trade and incomes do not explain changes in income disparities, the presence of regional DFIs (e.g. CABEI, EADB) with a relatively high loan exposure to GDP ration tends to reduce 
regional income disparities suggesting a useful role for deeper integration in achieving regional cohesion. A one percentage point increase in exposure by DFIs leads to a drop of ó of about one percentage point. We suggest that further growth analytical work is undertaken which combines the development of methods to examine the static and dynamic effects of regions and measurement of the various types of regional integration.

\section{Acknowledgements}

The paper has emerged from a study for the World Bank's World Development Report 2009. I am grateful to Steven Thompson and Chris Jones for research assistance. We are grateful to the comments from an anonymous referee.

Received 23 January 2010, Revised 5 February 2011, Accepted 7 February 2011

\section{References}

Aitken, B.J. and Harrison, A.E, (1999), Do Domestic Firms Benefit from Direct Foreign Investment? Evidence from Venezuela, American Economic Review, 89, 605-618.

Aziz Wane, A. (2004), Growth and Convergence in WAEMU Countries, IMF Working Paper, October 2004.

Blomstrom, M. A. Kokko (1997), Regional Integration and Foreign Direct Investment, NBER Working Papers 6019.

Carmignani, F. (2006), The Road to Regional Integration in Africa: Macroeconomic Convergence and Performance in COMESA, Journal of African Economies, Oxford University Press, 15(2), 212-250, June.

Coe, D. T., E. Helpman and A.W. Hoffmeister. (1997), North-South R\&D Spillovers, Economic Journal, 107, 134-49.

Coe, D.T., and E. Helpman. (1995), International R\&D Spillovers, European Economic Review, 39(5), 859-87.

Djankov, S. and B. Hoekman (2000), Foreign Investment and productivity Growth in Czech Enterprises, World Bank Economic Review, 14, 49-64.

Ethier, W. J. (1998), Regionalism in a multilateral world, Journal of Political Economy, 106, 1214-45.

Frankel, J., and A. Rose (2002), An Estimate of the Effect of Common Currencies on Trade and Income, Quarterly Journal of Economics, May.

Frankel, Jeffrey, (1997), Regional Trading Blocs in the World Trading System, Institute for International Economics, Washington.

Gasiorek, M. and P. Holmes (2008), Globalisation and Deep Integration, CARIS draft 
paper.

Ghura, D. and M. Hadjimichael (1996), Growth in Sub-Saharan Africa, IMF Staff Papers 43(3), 605-634.

Grossman, G.M. and E. Helpman (1991), Innovation and Growth in the Global Economy, MIT press, Cambridge, Massachusetts.

Haddad, M. and A. Harrison (1993), Are there positive spillovers from direct foreign investment? Evidence from panel data for Morocco, Journal of Development Economics, 42, 51-74.

Hammouda, B. S.N. Karingi, A.E. Njuguna, M.S. Jallab (2007), Why doesn't Regional Integration Improve Income Convergence in Africa?, UNECA paper.

Henrekson, M., J. Torstensson, and R. Torstensson. (1997), Growth Effects of European Integration, European Economic Review, 41(8), 1537-57.

Holmes, M. J. (2005), New evidence on Long-run output convergence among Latin American countries, Journal of Applied Economics, 8(2), 299-319.

IMF/World Bank. (2006), Doha Development Agenda and Aid for Trade, submitted to the Development Committee of the IMF and World Bank, Washington, D.C.

Jones, B. (2002), Economic Integration and Convergence of Per Capita Income in West Africa, African Development Review, 14, 18-47.

Levinsohn, James and Amil Petrin (2000), Estimating Production Functions Using Inputs to Control for Unobservables, Review of Economic Studies, 70(2), 317-341.

Levy Y.E., E. Stein and C. Daude (2002), Regional Integration and the Location of FDI, IADB Draft.

Meyn, M. and te Velde, D.W. (2008), Regional Integration in African, Caribbean and Pacific Countries. A Review of the Literature, Report for the EC's DG Development.

Mutoti, N. and D. Kihangire (2006), Macroeconomic convergence in COMESA, Bank of Uganda Working Paper, WP 01/2006.

Neary, J.P (2001), Foreign Direct Investment and the Single Market, Draft paper CEPR and University College Dublin.

Olley, Steven and Ariel Pakes (1996). The Dynamics of Productivity in the Telecommunications Equipment Industry, Econometrica, 64(6), 1263-1297.

Qureshi, M. and D.W. te Velde, (2007), State Business Relations and firm performance in Zambia, (Mahvash Qureshi and Dirk Willem te Velde), IPPG discussion paper 5, see http://www.ippg.org.uk/PDF/Firm\%20Performance\%20Zambia\%205.pdf

Rodrik, D. (1999), The new global economy and developing countries: making openness work, Washington D.C.: Overseas Development Council.

Schiff and Wang (2003), Regional Integration and Technology Diffusion. The case of the North American Free Trade Agreement, World Bank Policy Research Working Paper 3132 .

Soloaga, I. and A. Winters (2001), Regionalism in the Nineties: What Effect on Trade? North American Journal of Economics and Finance, 12(1).

Vamvakidis, A., (1998), Regional integration and economic growth, The World Bank Economic Review, 12(2), 251-270. 
Velde, D.W. te (2006), (ed), Regional Integration and Poverty, Ashgate.

Velde, D.W., te and D. Bezemer (2006), Regional Integration and Foreign Direct Investment in Developing Countries, Transnational Corporations, 15(2), (August 2006), 41-70.

Venables, A.J. (1999), Regional Integration Agreements; a force for convergence or divergence, World Bank Policy research paper.

Viner J. (1950), The customs union issue, New York, Carnegie Endowment for International Peace.

Countries for Annual Data for growth equations

\begin{tabular}{|c|c|}
\hline Algeria & Iran, Islamic Rep. \\
\hline Argentina & Kenya \\
\hline Bangladesh & Lesotho \\
\hline Benin & Madagascar \\
\hline Bolivia & Malawi \\
\hline Brazil & Malaysia \\
\hline Burkina Faso & Mali \\
\hline Cameroon & Mauritania \\
\hline Chad & Mexico \\
\hline Chile & Morocco \\
\hline Colombia & Nicaragua \\
\hline Congo, Dem. Rep. & Nigeria \\
\hline Congo, Rep. & Pakistan \\
\hline Costa Rica & Paraguay \\
\hline Cote d'Ivoire & Peru \\
\hline Dominican Republic & Philippines \\
\hline Ecuador & Rwanda \\
\hline Egypt, Arab Rep. & Senegal \\
\hline El Salvador & Sri Lanka \\
\hline Gabon & Sudan \\
\hline Gambia, The & Swaziland \\
\hline Ghana & Thailand \\
\hline Guatemala & Togo \\
\hline Guinea-Bissau & Trinidad and Tobago \\
\hline Guyana & Tunisia \\
\hline Honduras & Uruguay \\
\hline India & Zambia \\
\hline Indonesia & \\
\hline
\end{tabular}




\section{Appendices}

Which RTAs are included?

\section{In Africa we include:}

EAC: Kenya, Tanzania, Uganda (Burundi and Rwanda joined in 2007).

CEMAC: Cameroon, Gabon, Central African Republic, Chad, Equatorial Guinea, Congo, Rep.

WAEMU: Benin, Burkina Faso, Cote d'Ivoire, Guinea-Bissau, Mali, Niger, Senegal, Togo.

COMESA: Angola, Burundi, Comoros, Congo, Dem Rep, Djibouti, Egypt, Ethiopia, Kenya, Libya, Madagascar, Malawi, Mauritius, Rwanda, Seychelles, Sudan, Uganda, Zambia, Zimbabwe.

SADC: Botswana, Lesotho, Namibia, South Africa, Swaziland, Angola, Malawi, Mozambique, Tanzania, Zambia, Zimbabwe, Mauritius, Congo, Dem Rep, Madagascar, Seychelles.

SACU: Botswana, Lesotho, Namibia, South Africa, Swaziland.

\section{In Latin America:}

MERCOSUR: Brazil, Argentina, Uruguay, Paraguay.

CARICOM: Bahamas, Belize, Barbados, Jamaica, Guyana, Saint Vincent and the Grenadines, Saint Lucia, Saint Kitts and Nevis, Grenada, Dominica, Trinidad and Tobago, Suriname, Haiti, Grenada, Dominica, Montserrat.

NAFTA: United States, Mexico, Canada.

ANDEAN: Bolivia, Columbia, Ecuador, Peru.

\section{In Asia:}

ASEAN: Brunei, Cambodia, Indonesia, Laos, Malaysia, Myanmar, Philippines, Singapore, Thailand, Vietnam.

SAARC: Afghanistan, Bangladesh, India, Maldives, Nepal, Pakistan, Sri Lanka.

Developing country customs unions:

\section{Africa}

EAC: Kenya, Tanzania, Uganda (Burundi and Rwanda joined in 2007).

CEMAC: Cameroon, Gabon, Central African Republic, Chad, Equatorial Guinea, Congo, Rep. 
WAEMU: Benin, Burkina Faso, Cote d'Ivoire, Guinea-Bissau, Mali, Niger, Senegal, Togo.

SACU: Botswana (not in CU), Lesotho, Namibia, South Africa, Swaziland.

Other

MERCOSUR: Brazil, Argentina, Uruguay, Paraguay.

CARICOM: Bahamas, Belize, Barbados, Jamaica, Guyana, Saint Vincent and the Grenadines, Saint Lucia, Saint Kitts and Nevis, Grenada, Dominica, Trinidad and Tobago, Suriname, Haiti, Grenada, Dominica, Montserrat.

ANDEAN: Bolivia, Columbia, Ecuador, Peru.

GCC Cooperation Council of Arab States for the Gulf): Baharain, Saudi Arabia, Oman, Kuwait, Qatar, UAE.

CACM: Guatamala, El Salvador, Honduras, Nicaragua. 